\title{
Effect of Biofunctionalized Implant Surface on Osseointegration - A Histomorphometric Study in Dogs
}

\author{
Raquel R. M. BARROS \\ Arthur B. NOVAES Jr. \\ Vula PAPALEXIOU \\ Sérgio L. S. SOUZA \\ Mário TABA Jr. \\ Daniela B. PALIOTO \\ Márcio F. M. GRISI \\ Department of Oral and Maxillofacial Surgery and Traumatology and Periodontology, \\ Ribeirão Preto Dental School, University of São Paulo, Ribeirão Preto, SP, Brazil
}

\begin{abstract}
Among the different properties that influence bone apposition around implants, the chemical or biochemical composition of implant surface may interfere on its acceptance by the surrounding bone. The aim of this study was to investigate if a biofunctionalization of implant surface influences the bone apposition in a dog model and to compare it with other surfaces, such as a microstructured created by the grit-blasting/acid-etching process. Eight young adult male mongrel dogs had the bilateral mandibular premolars extracted and each one received 6 implants after 12 weeks, totaling 48 implants in the experiment. Four groups of implants were formed with the same microrough topography with or without some kind of biofunctionalization treatment. After histomorphometric analysis, it was observed that the modified microstructured surface with a "low concentration of the bioactive peptide" provided a higher adjacent bone density $(54.6 \%)$ when compared to the other groups (microstructured + HA coating $=46.0 \%$, microstructured only $=45.3 \%$ and microstructured + "high concentration of the bioactive peptide" $=40.7 \%$ ), but this difference was not statistically significant. In conclusion, biofunctionalization of the implant surface might interfere in the bone apposition around implants, especially in terms of bone density. Different concentrations of bioactive peptide lead to different results.
\end{abstract}

Key Words: bioactive peptide, dental implants, histomorphometric analysis, animal study.

\section{INTRODUCTION}

Knowledge regarding endosseous dental implants has rapidly expanded over the last years, making them a viable treatment alternative to replace missing teeth in many different situations with predictable high clinical success rates (1). Great part of this approach can be explained by the development of implant surfaces that improved implant anchorage with enhanced bone apposition $(2,3)$.

As a critical factor for osseointegration, the nature of the implant surface remains under investigation. Among the different surface properties that influence bone apposition around titanium implants, the topography has been extensively explored. It was recognized that microstructured surfaces provide higher success rates when compared to smooth or machined surfaces. Increased cell migration and proliferation (4) as well as enhanced bone apposition (5) and bone-to-implant contact (6) are some findings of in vitro and in vivo studies that support the superiority of the microstructured surfaces. Additionally, it has been shown that implants with this kind of rough surface require a greater torque for removal when compared to smooth surfaces (7), and also that implant roughness is important when immediate loading is to be applied (8). 
Bone is a complex composite in which a very large mineral component occurs in close association with collagen. Collagen comprises $>90 \%$ of the spatially fixed matrix of bone and is the major regulator of cell adhesion (9) and osteogenic differentiation (10), serving as conduit for a variety of biochemical and biomechanical signals between cells. Recently, some studies have focused on the mechanisms of interaction between proteins from the extra-cellular matrix (ECM) and cell membrane receptors $(11,12)$. Several of these biomolecules (native proteins and synthetic peptides) are known to control cell adhesion and growth. The most investigated mechanism for osteoblast adhesion implies the interaction with arginine-glycine-aspartic acid (RGD) peptide sequences via cell-membrane integrin receptors (13). Thus, the RGD sequence has been extensively used as a candidate peptide to enhance cell adhesion onto biomaterial surfaces (14).

Generally, the bone-to-implant interaction is complex and does not depend on surface topography only. Chemical or biochemical composition of implant surface also plays a key role in the early stages of bone formation $(15,16)$. Cell recruitment onto biomaterial surface is a fundamental step within the multifaceted process responsible for implant osseointegration. This process involves several proteins from the (ECM), cytoskeleton and cell membrane (17). Thus, it could be suggested that the biofunctionalization of implant surfaces, by associating on them adhesive factors to cells, may interfere in the acceptance and bonding of the implant to the surrounding bone. Biofunctionalized surfaces that mimic the bone tissue environment may be expected to enhance the performance of dental implants, encouraging the initial biologic response (17).

The purpose of this histomorphometric study was to investigate whether biofunctionalized implant surface containing a low or high concentration of a bioactive peptide influences the bone-implant contact and density around implants compared to standard grit-blasted and acid-etched implant surface.

\section{MATERIAL AND METHODS}

\section{Implant Design and Fabrication}

All implants were fabricated from commercially pure titanium following the XiVE design (Dentsply Friadent, Mannheim, Germany) and measured $4.5 \mathrm{~mm} x$
$9.5 \mathrm{~mm}$. The implants were characterized by an indentation placed $2.3 \mathrm{~mm}$ from the top of the implant with a depth of $0.18 \mathrm{~mm}$ and a height of $1.5 \mathrm{~mm}$ (Fig. 1). In this indentation, 4 different coatings were performed constituting the 4 different implant groups: A, B, C and D. Firstly, the indentations of all 4 groups were lined by the microstructured Friadent plus surface (Dentsply Friadent) provided by the sandblasting/acid-etching process. For biofunctionalization of the implant surface, a bioactive peptide was absorbed to nano-crystalline HA coatings and diluted in PBS solution. The bioactive peptide could also be described as a sequence of aminoacids related to bone formation; however the detailed composition has not been disclosed by the manufacturer (proprietary processing). Thus, group A was constituted by the Friadent plus surface morphology coated with nano-crystalline HA coating and a "low concentration" $(20 \mu \mathrm{g} / \mathrm{mL})$ of the bioactive peptide, while group D had the same characteristics but a "high concentration" $(200 \mu \mathrm{g} / \mathrm{mL})$ of the bioactive peptide. In group B, the implants were lined by the Friadent plus surface in conjunction with the nano-crystalline HA coating alone and group $\mathrm{C}$ was prepared only with the Friadent plus surface. It is important to emphasize that the Friadent plus surface morphology was not changed due to the surfaces' biofunctionalization process. The Friadent plus

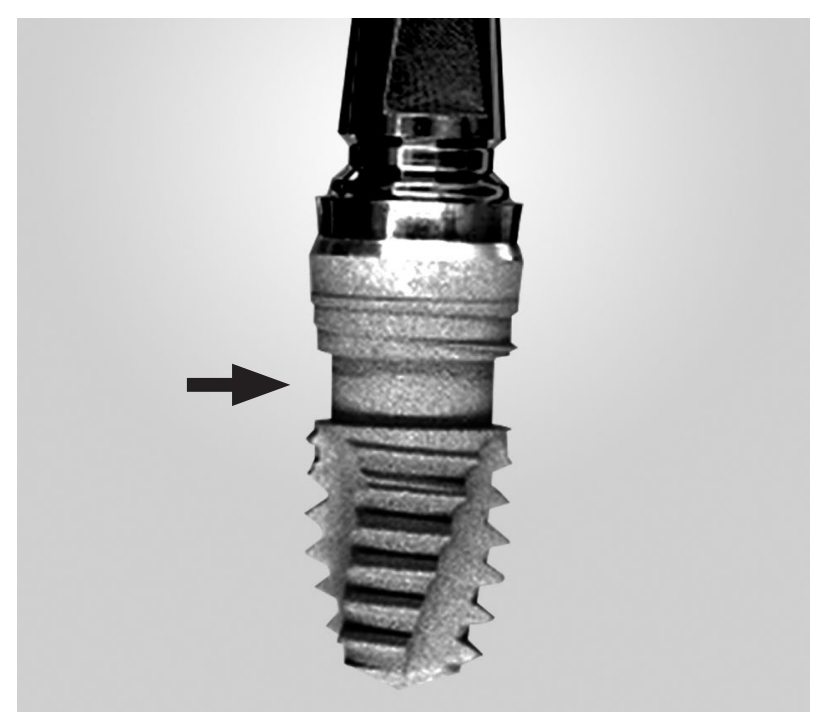

Figure 1. Implant design. All implants had the same shape and topography (grit-blasted/acid-etched surface), but received 4 different surface coatings performed in the indentation placed $2.3 \mathrm{~mm}$ from the top of the implant with $0.18 \mathrm{~mm}$ depth and 1.5 mm height (arrow). 
surface morphology was fully maintained following the application of a thin HA + bioactive peptide coating as seen in the scanning electron microcopy images (Fig. 2).

The study was blinded, that is, all involved professionals (from the surgeon to the examiner of the histologic specimens) had no knowledge of the constitution of the groups. The different coatings that characterized the 4 different implant surfaces were only revealed when the histomorphometric analysis was completed.

\section{Surgical Procedure}

The study protocol was approved by the institutional Animal Research Committee and involved 2 surgical interventions that were performed in 8 young adult male mongrel dogs, weighing approximately 12 $\mathrm{kg}$. The animals presented intact maxillas, no general occlusal trauma, no oral viral or fungal lesions, and were in good general health, with no systemic involvement as determined by a veterinarian following clinical examination.

In the first surgery, the dogs were sedated and anesthetized with an endovenous injection of thiopental $(1 \mathrm{~mL} / \mathrm{kg} ; 20 \mathrm{mg} / \mathrm{kg}$ thiopental diluted in $50 \mathrm{~mL}$ saline). Subsequently, full-thickness flaps were bilaterally elevated in the area of the 1st to 4th mandibular premolars. The teeth were sectioned in a buccolingual direction at the bifurcation so that the roots could be individually
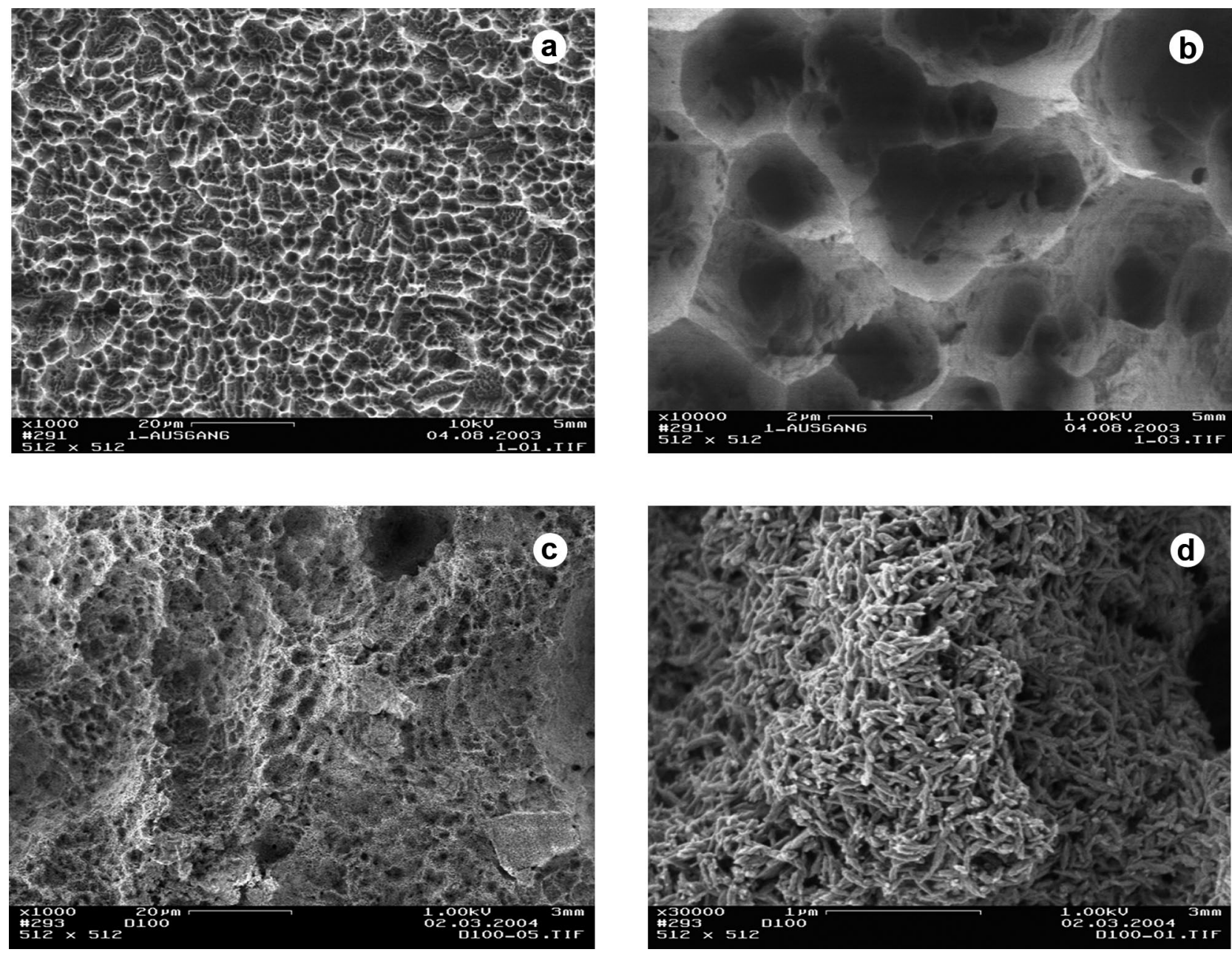

Figure 2. Panel of SEM micrographs. (A) View of the microstructured surface provided by sandblasting/acid-etching $(\times 1,000$ magnification); (B) The same microstructured surface at higher magnification $(\times 10,000$ magnification $)$; (C) The microstructured surface after coating with $\mathrm{HA}(\times 1,000$ magnification $)$, note the uniform coating not changing the original morphology; (D) The microstructured surface after coating with HA and adsorption of the bioactive peptide $(\times 10,000$ magnification). 
extracted, without damaging the bone walls, using a periotome. The flaps were repositioned and sutured with non-absorbable 4-0 sutures.

After a healing period of 3 months, the animals received 20,000 IU penicillin and streptomycin $(1.0 \mathrm{~g} / 10$ $\mathrm{kg}$ body weight) the night before the second surgery. This dose provides antibiotic coverage for 4 days, thus another dose was given 4 days later to provide coverage for a total of 8 days. After repeating the same sedation and anesthesia used in the first surgeries, horizontal crestal incisions were bilaterally performed from the distal region of the canine to the mesial region of the first molar. Three implants were randomly inserted in each side of the mandible of each animal. Thus, the locations and sides of the mandibles of the animals were treated with different sequences of implant groups. A total of 48 implants were disposed in the experiment, 12 for each group (A, B, C or D). The flaps were sutured with nonabsorbable sutures and the implants were left to heal in a submerged position. The animals were maintained on a soft diet for 14 days when the sutures were removed. The healing was evaluated periodically and the remaining teeth were cleaned monthly with ultrasonic tips.

\section{Sacrifice and Histological Processing}

The animals were sedated and sacrificed by anesthetic overdose 8 weeks after implant placement. The hemi-mandibles were removed, dissected and fixed in $4 \%$ phosphate-buffered formalin $\mathrm{pH} 7$, for 10 days, and transferred to a solution of $70 \%$ ethanol until processing. The specimens were dehydrated in a series of increasing ethanol concentrations up to $100 \%$, infiltrated and embedded in LR White resin (London Resin Company, Berkshire, England), and then hard-sectioned (18). The sections were prepared for histomorphometry and stained with Stevenel's blue and Alizarin red S for optical microscopy.

\section{Histomorphometric Analysis}

Longitudinal histological sections from each implant were captured through a video camera Leica DC 300F (Leica Microsystems GmbH, Nussloch, Germany) joined to a stereomicroscope Leica MZFL III (Leica Microsystems GmbH, Nussloch, Germany). The images were analyzed using the Image J program (National Institutes of Health, Bethesda, MD, USA), to determine the percentages of bone-to-implant contact (BIC) and bone density within the indentations.

The percentages of mineralized bone in direct contact with the implant surface (BIC) were determined within the indentations by linear measurements (19). The bone density was determined within two rectangles, one of them inside the indentation (BDA), occupying its total area, and the other outside the indentation (BDD) as mirror image of the first. The bone density measurements evaluated the percentages of mineralized bone in relation to the percentages of marrow cavities. A single examiner blinded to the made all measurements.

\section{Statistical Analysis}

The values of bone-implant contact and bone density were statistically analyzed using a mixed linear model for multiple variables and a standard 2-sample ttest for a single variable. In the mixed linear model with the SAS/STAT software (SAS Inst. Inc., Cary, NC, USA) a compound-symmetry covariance structure between the data was assumed to perform 2 repeated- measurements (side, surface). Repeated measurements within the same animal were done using a Tukey-adjusted multiple mean value comparison. The independent 2 sample t-test was applied between all mean values within different surface modifications using the SPSS software (SPSS GmbH Software, München, Germany).

\section{RESULTS}

After implant placement, healing progressed uneventfully during the 8 -week postoperative period without significant signs of inflammation. The radiographic evaluation of the implants immediately before the sacrifice revealed normal bone conditions, thus the total sample of 48 implants (12 of each group) were analyzed histomorphometrically.

\section{Histologic Observations}

The bone-implant interface had mineralized bone matrix in intimate contact with the implant surface in the 4 groups.

The bone tissue was characterized by the presence of concentric or parallel lamellar formations. Central canals of different diameters lined by endosteum were observed and were in close contact with the implant 
surface at some points (Fig. 3).

\section{Histomorphometric Findings}

The implant surface characterization of each experimental group A, B, C or D was previously described. The histomorphometric results of the percentages of direct BIC within the implant indentations (Table 1) revealed that the highest mean value of $65.4 \pm 17.1 \%$
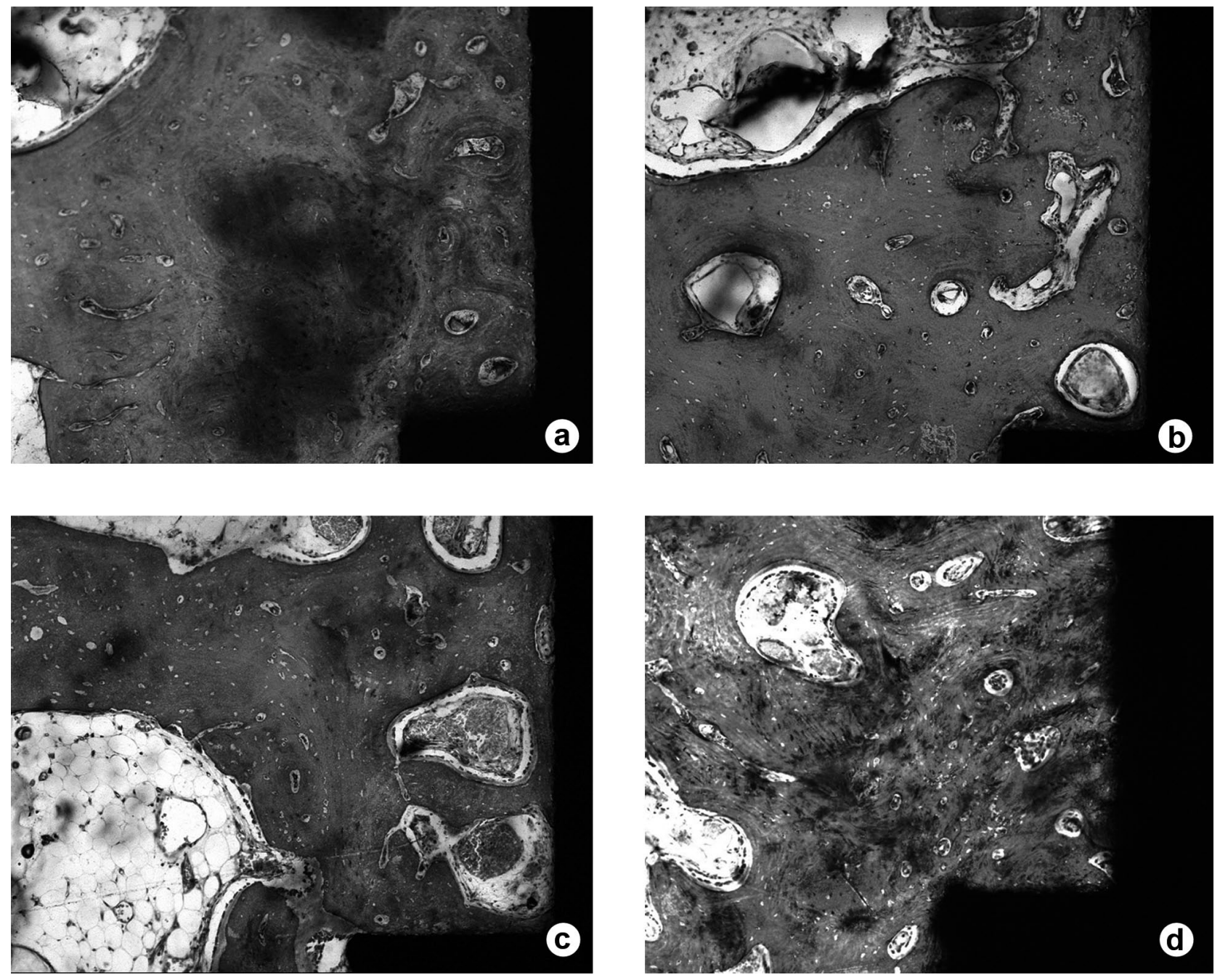

Figure 3. Histological images (Stevenel's blue and Alizarin red S staining) obtained in a close-up view of the indentation area of each experimental surface. (A) Group A implant (microstructured surface modified with a "low concentration" of the bioactive peptide). Observe a strict contact between bone and implant and a high histological bone density with just a few marrow spaces adjacent to the implant surface; (B) Group B implant (microstructured surface in conjunction with the nano-crystalline HA coating). Observe a high percentage of bone-to- implant contact and central canals of different diameters; (C) Group C implant (microstructured surface only). Observe a superior number of marrow spaces, which presents bigger diameters when compared to the other histological images; (D) Group D implant (microstructured surface modified with a "high concentration" of the bioactive peptide). Note good levels of boneto-implant contact and histological bone density. for group D (ranging from 20.8 to $88.5 \%$ ). In sequence, 28.9 to $96.2 \%$ ), group A $60.4 \pm 17.5 \%$ (ranging from 28.1 to $90.5 \%$ ) and, finally, group $\mathrm{C}$ that showed a numerically inferior BIC mean of $58.0 \pm 11.8 \%$ (ranging from 38.7 to $72.5 \%$ ) when compared to the other groups. No statistically significant differences $(p>0.05)$ were detected between the groups.

Bone density analysis revealed that the percentage group B had a BIC mean of $62.4 \pm 17.4 \%$ (ranging from 
of bone in adjacent areas for group A was $54.6 \pm 16.6 \%$ (ranging from 30.8 to $78.9 \%$ ); for group B it was $46.0 \pm$ $21.0 \%$ (ranging from 16.1 to $87.7 \%$ ); for group C $45.3 \pm$ $11.3 \%$ (ranging from 28.4 to $62.4 \%$ ) and for group D 40.7 $\pm 15.3 \%$ (ranging from 17.4 to $64.0 \%$ ) (Table 1 ). However, the differences between the groups were not statistically significant $(\mathrm{p}>0.05)$. The average of bone densities in areas distant from the implants was $47.0 \pm 16.8 \%$ (ranging from 15.2 to $68.9 \%$ ) for group A, $44.9 \pm 17.5 \%$ (ranging from 16.5 to $87.0 \%$ ) for group B, $44.6 \pm 14.6 \%$ (ranging from 21.8 to $75.6 \%$ ) for group $\mathrm{C}$ and $41.4 \pm 18.7 \%$ (ranging from 12.7 to $68.4 \%$ ) for group D (Table 1) and again the results were not statistically significant $(\mathrm{p}>0.05)$.

\section{DISCUSSION}

A new strategy to improve endosseous implant integration is based on preparing biofunctionalized surfaces with inclusion of cell adhesive factors, for example.

Cell adhesion is a fundamental process directly involved in cell growth, cell migration, and cell differentiation. It is concerned in embryogenesis, maintenance of tissue integrity, wound healing, immune response, and biomaterial tissue integration. Several proteins are involved in cell adhesion, such as extracellular matrix proteins (collagen, fibronectin, vitronectin) and membrane receptors (integrins). Interactions between these proteins and their specific receptors induce signal transduction and consequently influence cell growth and differentiation (11).

The development of bone-implant interfaces depends on the direct interactions of bone matrix and osteoblasts with the biomaterial. Osteoblast adhesion is therefore essential for bone-biomaterial interactions (11).

It has been shown in vitro that a functionalized titanium substrate with synthetic peptides may enhance the adhesion of human osteoblast-like cells (17). The presence of synthetic peptides also demonstrates an increase in the osteogenic gene expression for alkaline phosphatase and for BMP-2 and BMP-7. These BMPs have been reported to stimulate osteoblastic activity through autocrine and paracrine mechanisms (20).

In the present study, (BDA) and bone density/distant (BDD).

\begin{tabular}{|c|c|c|c|c|c|c|}
\hline Group & $\mathrm{n}$ & Variable & Mean* & $\mathrm{SD}^{*}$ & $\begin{array}{l}\text { Minimum } \\
\text { value }\end{array}$ & $\begin{array}{l}\text { Maximum } \\
\text { value }\end{array}$ \\
\hline \multirow{3}{*}{ A } & \multirow{3}{*}{12} & BIC & 60.41 & 17.56 & 28.10 & 90.50 \\
\hline & & BDA & 54.67 & 16.63 & 30.80 & 78.90 \\
\hline & & BDD & 47.07 & 16.84 & 15.20 & 68.90 \\
\hline \multirow{3}{*}{ B } & \multirow{3}{*}{12} & BIC & 62.43 & 17.44 & 28.90 & 96.20 \\
\hline & & BDA & 46.02 & 21.04 & 16.10 & 87.70 \\
\hline & & BDD & 44.99 & 17.53 & 16.50 & 87.00 \\
\hline \multirow{3}{*}{$\mathrm{C}$} & \multirow{3}{*}{12} & BIC & 58.00 & 11.85 & 38.70 & 72.50 \\
\hline & & BDA & 45.30 & 11.35 & 28.40 & 62.40 \\
\hline & & BDD & 44.66 & 14.64 & 21.80 & 75.60 \\
\hline \multirow{3}{*}{ D } & \multirow{3}{*}{12} & BIC & 65.41 & 17.17 & 20.80 & 88.50 \\
\hline & & BDA & 40.71 & 15.37 & 17.40 & 64.00 \\
\hline & & BDD & 41.42 & 18.78 & 12.70 & 68.40 \\
\hline
\end{tabular}

$\mathrm{n}=$ number of implants in each group. *Percent values expressed as means and standard deviation (SD). a biofunctionalized implant surface with different concentrations of a bioactive peptide was tested in an animal model, providing histomorphometric analysis of the bone density and bone-implant contact. The modified Friadent plus-surface with a low concentration of the bioactive peptide (group A implants) provided a higher adjacent bone density $(54.6 \%)$ when compared with the other group surfaces (group B $=46.0 \%$, group $\mathrm{C}=45.3 \%$ and group $\mathrm{D}$ $=40.7 \%$ ). The difference was only numeric, without statistical significance, which may be partially due to the sample size. The average of bone density in areas distant from the implants was also higher in the group A, but not as evident as the other 
parameter. According to the histograms (Fig. 4) that show the dispersion of the bone density values for all implant surface groups, the group A achieved a better performance when compared with the other groups. In this group, 7 out of 12 implants showed $40-60 \%$ of BDA, 3 implants achieved more than $70 \%$ of BDA and no implants had less than $30 \%$ of BDA. The presence of a high concentration of the bioactive peptide did not provide any advantages considering the group A bone density results. Although 6 out of 12 implants showed $40-60 \%$ of BDA in the group D, no implants achieved more than $70 \%$ of BDA and 3 implants had less than $30 \%$ of BDA. Thus it could be concluded that the concentration of the bioactive peptide interferes in the bone apposition process and that the low concentration was
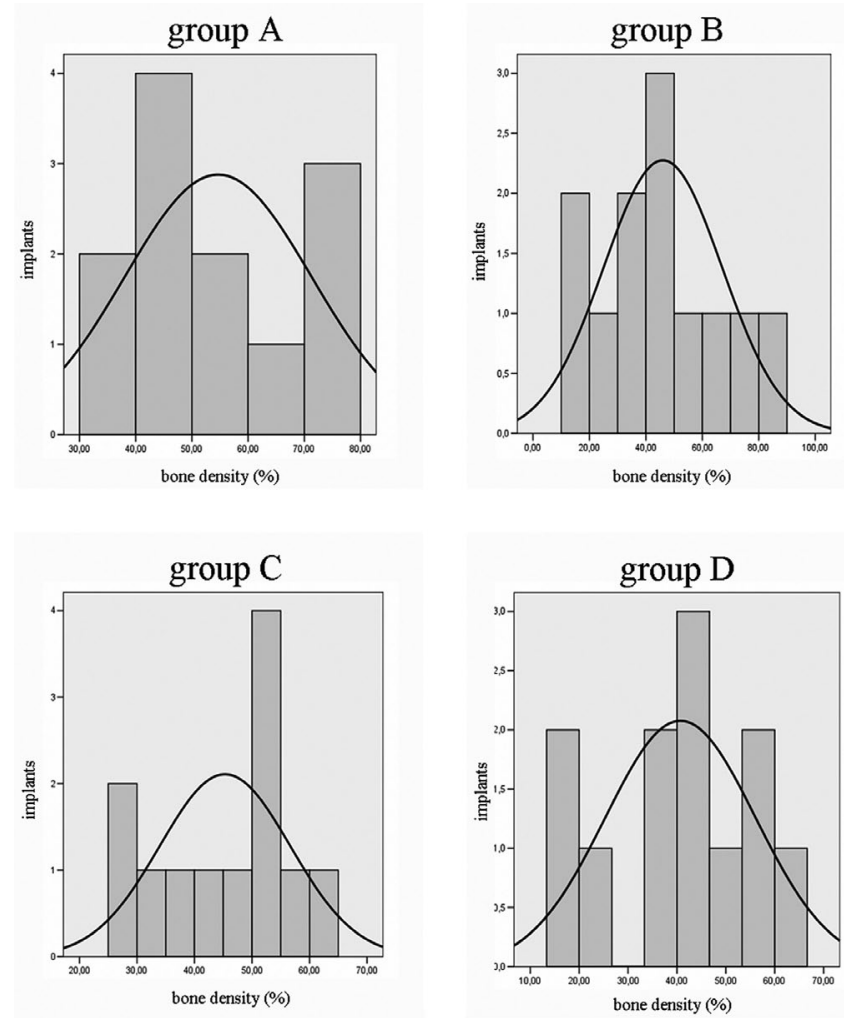

Figure 4. Histograms showing the dispersion of bone density (BD) values for all implant surface groups. (A) In group A 7 implants from 12 showed $40-60 \%$ of BD, 3 implants achieved more than $70 \%$ and no implants had less than 30\%; (B) In group B 5 implants from 12 showed $40-60 \%$ of BD, 2 implants achieved more than $70 \%$ and 3 implants had less than 30\%, (C) In group C 6 implants from 12 showed $40-60 \%$ of $\mathrm{BD}$, no implants achieved more than $70 \%$ and 2 implants had less than $30 \%$; (D) In group D 6 implants from 12 showed $40-60 \%$ of BD, no implants achieved more than $70 \%$ and 3 implants had less than $30 \%$. better than the high concentration. The histogram analysis also shows that the group $\mathrm{C}$ exhibited inferior results when compared with group A. In this group $\mathrm{C}$, which represents the grit-blasted/acid-etched implant surface (Friadent plus surface), 6 out of 12 implants the showed $40-60 \%$ of BDA, but no implants achieved more than $70 \%$ of BDA and 2 implants had less than $30 \%$ of BDA. Finally, in group B (Friadent plus surface in conjunction with the nano-crystalline HA coating alone), 5 out of 12 implants showed $40-60 \%$ of BDA, 2 implants achieved more than $70 \%$ of BDA and 3 implants had less than $30 \%$ of BDA. These results indicate that biofunctionalization could positively interfere in the bone apposition process. Germanier et al. (15) recently observed in an in vivo study that the topography is not the only surface characteristic capable of enhancing new bone apposition. Besides, Schuler et al. (16) showed in an in vitro study that surface chemistry also influenced the attachment and morphology of cells. In general, an increase in cell number and more spread cells were observed on bioactive substrate (containing RGD) compared to bio-inactive surfaces according to their findings. In the present study, it is not possible to describe exactly how the low bioactive peptide concentration coating acts during bone healing; one hypothesis is that the improvement of the surface biochemical composition was able to enhance its ability to interact with cells by mechanisms that simulate the interaction of cells with their extracellular matrices.

Interestingly, the low concentration modified Friadent plus surface did not show higher BIC mean values when compared to the other surfaces. Instead, statistically similar mean values were observed for the 4 groups $(\mathrm{A}=60.4 \%, \mathrm{~B}=62.4 \%$, $\mathrm{C}=58.0 \%$ and $\mathrm{D}=65.4 \%$ ). According to the results, it may be concluded that the establishment of the bone-to-implant contact was influenced mainly by the underlying pore structure of the Friadent plus surface, which was not altered by the biofunctionalization. However, further research is required.

Biofunctionalization of implant surfaces is still a poorly investigated area. The enhancement of bone density around the modified-Friadent plus surface (low concentration of bioactive peptide) is promising. Further in vitro and in vivo studies are necessary to elucidate how and in which extent biofunctionalization of the implant surfaces could 
represent an advantageous modification.

In conclusion, biofunctionalization of implant surface interferes in bone apposition around titanium implants, especially in the bone density, and different bioactive peptide concentrations lead to different results.

\section{RESUMO}

Entre as diferentes propriedades de uma superfície capazes de influenciar a deposição óssea ao redor de implantes, a composição química e bioquímica pode atuar no reconhecimento do tecido ósseo circundante. O presente trabalho investigou a influência da biofuncionalização de superfícies de implante na deposição óssea ao redor dos mesmos em um modelo animal, comparandoas com outras superfícies, como a microtexturizada obtida pelo processo de jateamento e ataque ácido. Metodologicamente, os pré-molares mandibulares bilaterais de 8 cães foram extraídos e após 12 semanas foram instalados 6 implantes em cada cão, constituindo uma amostra de 48 implantes. Dos 4 grupos experimentais de diferentes superfícies, todos continham a mesma microtopografia rugosa, porém possuindo ou não alguma biofuncionalização. A análise histomorfométrica revelou que a superfície microtexturizada modificada pela adição de baixa concentração peptídica obteve uma maior densidade óssea adjacente $(54,6 \%)$ quando comparada aos outros grupos (microtexturizada $+\mathrm{HA}=$ $46 \%$, somente microtexturizada $=45,3 \%$ e microtexturizada com adição de alta concentração peptídica $=40,7 \%$ ), no entanto estas diferenças numéricas não foram estatisticamente significantes. Dentro deste contexto, conclui-se que a biofuncionalização da superfície de implantes pode interferir na aposição óssea, em particular na densidade óssea, e que diferentes concentrações peptídicas podem conduzir a diferentes resultados.

\section{ACKNOWLEDGEMENTS}

This study was supported in part by Dentsply Friadent and by the São Paulo State Research Foundation (FAPESP - grants \#05/60839-8 and \#06/56020-6). The authors are grateful to Mr. Sebastião Carlos Bianco from the Laboratory of the Department of Oral and Maxillofacial Surgery and Traumatology and Periodontology of Ribeirão Preto Dental School, University of São Paulo, Brazil, for his assistance in the histological processing.

\section{REFERENCES}

1. Adell R, Lekholm U, Rockler B, Bränemark PI. A 15-year study of osseointegrated implants in the treatment of the edentulous jaw. Int J Oral Surg 1981;10:387-416.

2. Cochran DL. A comparison of endosseous dental implant surfaces. J Periodontol 1999;70:1523-1539.

3. Ferguson SJ, Langhoff JD, Voelter K, von Rechenberg B, Scharnweber D, Bierbaum S, et al.. Biomechanical comparison of different surface modifications for dental implants. Int J Oral Maxillofac Implants 2008;23:1037-1046.

4. Zinger O, Zhao G, Schwartz Z, Simpson J, Wieland M, Landolt $D$, et al.. Differential regulation of osteoblasts by substrate microstructural features. Biomaterials 2005;26:1837-1847.
5. Bornstein MM, Valderrama P, Jones AA, Wilson TG, Seibl R, Cochran DL. Bone apposition around two different sandblasted and acid-etched titanium implant surfaces: a histomorphometric study in canine mandibles. Clin Oral Implants Res 2008;19:233-241.

6. Le Guehennec L, Goyenvalle E, Lopez-Heredia MA, Weiss P, Amouriq Y, Layrolle P. Histomorphometric analysis of the osseointegration of four different implant surfaces in the femoral epiphyses of rabbits. Clin Oral Implants Res 2008;19:1103-1110.

7. Sykaras N, Iacopino AM, Marker VA, Triplett RG, Woody RD. Implants materials, designs, and surfaces topographies: their effect on osseointegration. A literature review. Int J Oral Maxillofac Implants 2000;15:675-690.

8. Uribe R, Penarrocha M, Balaguer J, Fulgueiras N. Immediate loading in oral implants. Present situation. Med Oral Patol Oral Cir Bucal 2005;10:143-153.

9. Kleinman HK, Klebe RJ, Martin GR. Role of collagenous matrices in the adhesion and growth of cells. J Cell Biol 1981;88:473-485.

10. Mizuno M, Kuboki Y. TGF-beta accelerated the osteogenic differentiation of bone marrow cells induced by collagen matrix. Biochem Biophys Res Commun 1995;211:1091-1098.

11. Anselme K, Bigerelle M, Noel B, Dufresne E, Judas D, Iost A, et al.. Qualitative and quantitative study of human osteoblast adhesion on materials with various surface roughnesses. J Biomed Mater Res 2000;49:155-166.

12. MacDonald DE, Markovic B, Allen M, Somasundaran P, Boskey AL. Surface analysis of human plasma fibronectin adsorbed to commercially pure titanium materials. J Biomed Mater Res 1998;41:120-130.

13. Xiao Y, Truskey GA. Effect of receptor-ligand affinity on the strength of endothelial cell adhesion. Biophys J 1996;71:2869-2884.

14. Rezania A, Healy KE Biomimetic peptide surfaces that regulate adhesion, spreading, cytoskeletal organization, and mineralization of the matrix deposited by osteoblast-like cells. Biotechnol Prog 1999;15:19-32.

15. Germanier Y, Tosatti S, Broggini N, Textor M, Buser D. Enhanced bone apposition around biofunctionalized sandblasted and acidetched titanium implant surfaces. A histomorphometric study in miniature pigs. Clin Oral Impl Res 2006;17:251-257.

16. Schuler M, Owen GR, Hamilton DW, de Wild M, Textor M, Brunette DM, et al.. Biomimetic modification of titanium dental implant model surfaces using the RGDSP-peptide sequence: a cell morphology study. Biomaterials 2006;27:4003-4015.

17. Bagno A, Piovan A, Dettin M, Chiarion A, Brun P, et al.. Human osteoblast-like cell adhesion on titanium substrates covalently functionalized with synthetic peptides. Bone 2007;40:693-699.

18. Shibli JA, Grassi S, Piattelli A, Pecora GE, Ferrari DS, Onuma $\mathrm{T}$, et al.. Histomorphometric evaluation of bioceramic molecular impregnated and dual acid-etched implant surfaces in the human posterior maxilla. Clin Implant Dent Relat Res 2009;23. [Epub ahead of print].

19. Novaes Jr AB, Souza SLS, Oliveira PT, Souza AMMS. Histomorphometric analysis of the bone-implant contact obtained with 4 different implant surface treatments placed side by side in the dog mandible. Int J Oral Maxillofac Implants 2002;17:377-383.

20. Ripamonti U, Reddi AH. Growth and morphogenetic factors in bone induction: role of osteogenin and related bone morphogenetic proteins in craniofacial and periodontal bone repair. Crit Rev Oral Biol Med 1992;3:1-14. 